\title{
Ehlers-Danlos Syndrome, Type VI
}

National Cancer Institute

\section{Source}

National Cancer Institute. Ehlers-Danlos Syndrome, Type VI. NCI Thesaurus. Code C125700.

Ehlers-Danlos syndrome, type VI is the kyphoscoliosis type Ehlers-Danlos syndrome. It results from mutations in the PLOD1 gene. 